\title{
A multimodal analysis of cognitive tools portraying terrorist affairs
}

\author{
$\mathrm{M}^{\mathrm{a}}$ Enriqueta Cortés de los Ríos ${ }^{1}$ \\ Universidad de Almería \\ Patricia Fernández Alonso \\ Universidad de Almería
}

\begin{abstract}
A multimodal analysis of the communication of terrorism has scarcely been tackled. This study aims to explore how verbal and pictorial modes contribute to the creation of a particular conceptualization of terrorism by means of cognitive tools on different front covers of The Economist, the prestigious business and current affairs magazine. The analysis has been structured according to the Cognitive Theory of Metaphor and Metonymy and Multimodal Discourse (among others, see Lakoff \& Johnson, 1980; Johnson, 1987; Evans \& Green, 2006; and Forceville, 2009, 2012). Our method of analysis focuses on Forceville $(1996,2009,2012)$ and Forceville \& Urios-Aparisi (2009), who provide clear instructions for the identification of cognitive devices in multimodal discourse. The data collection for the analysis consists of ten of this magazine's covers, published in the period 2014-2016, dealing with terrorist attacks and immigration. The results of this analysis reveal that metaphors, metonymies and image schemas are more prevalent in the visual than the verbal mode. This shows how important pictorial representations have become to the communication of terrorism. The use of metonymies is greater than metaphors. By means of the WAR and JOURNEY domains and the use of the FIRE domain to reinforce the former, the terrorist situation is cognitively represented. Colours, considered as cognitive tools which fulfill the evaluative meaning of a particular topic, have also been taken into account. In our analysis they stand out as a sign of negativity reinforcing the horrors of war and the threat towards the people trying to escape an uncertain future.
\end{abstract}

Keywords: terrorism communication, metaphor, metonymy, multimodality, image schemas

1 Corresponding author - Universidad de Almería, C/ Sacramento, s/n, La Cañada de San Urbano, 04120 Almería (España).

Email: mecortes@ual.es 


\section{RESUMEN}

Un análisis multimodal de la comunicación del terrorismo apenas ha sido abordado. Este estudio pretende explorar cómo modalidades verbales y pictóricas contribuyen a la creación de una particular conceptualización del terrorismo por medio de herramientas cognitivas en diferentes portadas de The Economist, prestigiosa revista de temas económicos de actualidad. El análisis se ha estructurado según la Teoría Cognitiva de la Metáfora y Metonimia y del Discurso Multimodal (entre otros, véase Lakoff y Johnson, 1980; Johnson, 1987; Evans y Green, 2006; y Forceville, 2009, 2012). Nuestro método de análisis se centra en Forceville (1996, 2009, 2012) y Forceville y UriosAparisi (2009), que proporcionan instrucciones claras para la identificación de los mecanismos cognitivos en el discurso multimodal. El corpus para el análisis consta de diez portadas de dicha revista, publicadas en el período 2014-2016, relacionadas con la inmigración y los ataques terroristas. Los resultados de este análisis revelan que las metáforas, metonimias y los esquemas de imagen se manifiestan más frecuentemente en la modalidad pictórica que en la verbal. Esto muestra la importancia de las representaciones pictóricas en la comunicación del terrorismo. El uso de metonimias es mayor que el de metáforas. Por medio de los dominios GUERRA y VIAJE, junto con el uso del dominio FUEGO para reforzar el primero, la situación terrorista queda representada cognitivamente. Los colores, considerados como herramientas cognitivas que conllevan el significado evaluativo de un tema en particular, se han tenido también en cuenta. En nuestro análisis destacan como un signo de negatividad reforzando los horrores de la guerra y la amenaza a la gente que trata de escapar de un futuro incierto.

Palabras clave: comunicación del terrorismo, metáfora, metonimia, multimodalidad, esquemas de imágenes

\section{Introduction}

Over the last few years, the increasing power of ISIS (Islamic State in Iraq and Syria) has been a major concern for the Western world. This terrorist organization aims to create a caliphate and rule over all the Muslims in the world. They believe that destroying the Western heretic and conquering more and more territories in the name of their religion is Allah's wish, so they have attacked a lot of countries around the world. However, the civil war in Syria has turned this country into a place that is no longer safe to live. As a result, thousands of inhabitants are risking their lives trying to cross the sea and start a new life in Europe. This means Western countries are now facing two problems; on the one hand, they have to put an end to the threat of ISIS and, on the other hand, they have to give shelter to all the migrants. The focus of this paper is on the multimodal analysis of some of the front covers of The Economist magazine at the time when the terrorist attacks and immigration were intensified in late 2014. More precisely, we will tackle the topic of terrorism, examining, in line with the main postulate of multimodality, how different modes are used to create meaning, both verbal and pictorial. We will try to determine how terrorism is communicated on some covers in an attempt to discover how these modes contribute to the creation of a particular conceptualization of terrorism by means of cognitive tools. As a result, we will analyze how it is communicated through cognitive 
devices such as metaphor, metonymy and image schemas, together with colour. As we will develop later on, these tools help the journalist to show reality in a certain way and to shape our thoughts, behaviour and reactions. The magazine front covers try to inform readers of current events as well as to influence their line of reasoning about such events, combining verbal and visual modes. In consequence, they turn into persuasive messages. As Gudrun (2005, p. 173) states:

\begin{abstract}
Magazine covers are omnipresent contact texts. Their multimodal character, which combines visual and verbal elements into complex persuasive messages, has a great influence on the competitive press market. Their function as a label or even a window, can be considered an important pretext which announces, indicates and appraises subsequent texts inside the magazine.
\end{abstract}

In addition, Cortés de los Ríos (2010, p. 84) claims that "a cover can be described as an important form of self-advertising that offers a vision of the world and of reality, and they present a strong symbolic meaning, seeking the greatest visual impact in order to transmit emotions". In light of this function, this paper intends to give a first overview of the most important visual and verbal means included on selected covers of The Economist, compiled between 2014 and 2016 and created just to capture the reader's attention. As far as we know, a multimodal approach of the communication of terrorist issues such as terrorist attacks and immigration has not been developed yet and as a consequence, we will try to fill in this gap. However, it is worth mentioning that previous studies about the communication of terrorism are conducted from different perspectives such as Wan Min (2007) and O'Halloran et al. (2016).

The layout of this paper is the following. The theoretical background of this topic is given in Section 2. The third Section includes the corpus and methodology. The fourth presents the analysis of the chosen covers. In Section 5 we discuss our findings and finally we draw some conclusions.

\title{
2. Theoretical background
}

The theoretical underpinnings are based on the Cognitive Theory of Metaphor and Metonymy (Lakoff \& Johnson, 1980; Charteris-Black \& Musolf, 2003; Ruiz de Mendoza \& Pérez, 2011; among others) on the one hand, and the Theory of Multimodal Discourse (Forceville, 1996, 2009, 2012; Forceville \& Urios-Aparisi, 2009, among others) on the other, in which meaning is created through modes of communication other than verbal. Previous studies of cognitive tools have focused on different fields of ESP such as advertising (for example, Forceville, 1996, 2009, 2012; Ungerer, 2000; Cortés de los Ríos \& Azzahara, 2014; Cruz García, 2016; Cortés de los Ríos \& Corral Hernández, 2016), politics (Charteris-Black, 2006; Negro Alousque, 2014), scientific discourse (Cuadrado Esclapez, 2005; Kheovichai, 2015), and economics (White, 1996; Silaski \& Durovic, 2010; 
Langer, 2015), in which cognitive tools were used for a persuasive purpose. Some preceding studies about verbal metaphors on terrorism have been carried out by some researchers. Judge (2005) identified the following source domains: haystack and needle, cancer, franchise, fire, chemical radical, root (evil tree) and log-jam or silver bullet. Later, Bathia (2009) added another one: tyranny. Spencer (2012) identified the following ones: war, crime, uncivilized evil and disease. Finally, Pavlíková (2015) recognised conflict, morality, journey, building, light and darkness, fire, nature, disease, violence and human being metaphors.

\subsection{Cognitive Theory of Metaphor and Metonymy}

Lakoff \& Johnson's Metaphors We Live By (1980) was a breakthrough because it challenged traditional views on metaphor and metonymy and it outlined a theory that goes beyond linguistics by aiming to explain how we think and how we behave. According to them, metaphors and metonymies are not only figures of speech but also tools that rely on our bodily experience to make sense of the world, to shape our thoughts, behavior and linguistic expressions. This is why Lakoff \& Johnson (1999, p. 3) claim that "the mind is inherently embodied". Ungerer \& Schmid (1996, p. 114) affirmed that "metaphors and metonymies are powerful cognitive tools for our conceptualization of abstract categories." According to Lakoff \& Johnson (1980, p. 3) "metaphor is pervasive in everyday life, not just in language but in thought and action". Barcelona (2000) pointed out that metaphor and metonymy became two of the main subjects of study for cognitive linguists. Since Lakoff \& Johnson's publication subsequent studies were published such as Croft \& Cruse, 2004; Panther, Thornburg \& Barcelona, 2009; Ruiz de Mendoza \& Galera Masegosa, 2014.

Metaphors follow the pattern A IS B. One of the most common examples is ARGUMENT IS WAR. The purpose of a metaphor is to help us understand an abstract concept, thanks to our knowledge and experience, through a more concrete one. Thus, we apply what we know about 'war' (the source domain) to 'argument' (the target domain). Not only does this metaphor manifest itself in expressions such as I've never won an argument with him or You disagree? Okay, shoot! but also in the way we behave and understand what happens when we have an argument. However, since the features of a single source domain only cover one aspect of the target domain, we need different source domains in order to understand the latter fully. Thus, an argument can also be a building, a container, etc.

As for metonymies, these are used to refer to something by using the name of another thing instead. Unlike metaphors, metonymies involve only one conceptual domain, i.e. the mapping occurs within a single domain and not across domains. In metonymy there is a "stand for" relationship since one entity in a schema is taken to stand for another 
entity in the same domain or for the domain as a whole. Lakoff \& Johnson (1980, pp. 3839) identify several kinds of metonymies: the part for the whole (e.g. We don't hire longhairs), producer for product (e.g. He bought a Ford), object used for user (e.g. The sax has the flu today), controller for controlled (e.g. Nixon bombed Hanoi), institution for people responsible (e.g. You'll never get the university to agree to that), the place for the institution (e.g. The White House isn't saying anything), and the place for the event (e.g. Let's not let Thailand become another Vietnam). In addition, Ruiz de Mendoza \& Otal (2002, p. 58) suggest two types of metonymy based on the domain-internal nature of metonymic mappings:

a) Source-in-target metonymies are those in which the source domain is a subdomain of the target domain. An example of this type of metonymy would be: We need more hands in the farm, where hands refers to the workers, thus hands appears as a subdomain of the wider domain WORKERS.

b) Target-in-source metonymies are those in which the target is a subdomain of the source. She is learning to tie her shoes could be an example which illustrates this kind of metonymies. Here the concept shoes refers to laces. As we can observe this is a typical case of a conventional metonymy where THE WHOLE stands for PART OF THE WHOLE.

Furthermore, there are two main ways in which metonymy and metaphor interact with each other: "one in which the experiential basis for the metaphor is a metonym, yielding what we called metaphor from metonymy. The other in which a metonym functioning in the target domain is embedded within a metaphor, i.e. metonymy within metaphor" (Goosens, 1995, p. 174).

As for image schemas, these provide the basis for a large number of metaphoric (Lakoff, 1987; Lakoff \& Johnson, 1980, 1999; Johnson, 1987; Lakoff \& Turner, 1989) and metonymic mappings and underlie metaphor-metonymy interaction (Díez, 2001). The first author that addressed image schemas was Johnson (1987, pp. xiv and xvi), who described them as:

A recurring dynamic pattern of our perceptual interactions and motor programs that gives coherence and structure to our experience [...] "Experience" [...] is to be understood in a very rich, broad sense as including basic perceptual, motor-program, emotional, historical, social and linguistic dimensions.

Evans \& Greens (2006, p. 176) also contributed to the development of this device and offered their own definition. They considered image schemas as "relatively abstract conceptual representations that arise directly from our everyday interaction with and observation of the world around us". This means that we are not born with this knowledge, although it is acquired during our early childhood, which is the reason why we are not even aware of it. For example, the fact that we have a head at the top of our 
body and feet at the bottom, that we walk upright, and gravity exists, determines the way we interact with our environment. Given all these conditions, if we want to pick up an object from the floor, we have to stop and bend down. From this experience we infer the schema UP-DOWN, but there are plenty more.

According to Krzeszowski (1993), each pair of concepts follows a PLUS-MINUS parameter, which means that the first concept has a positive value and the second one, a negative value. For example, let us consider the container schema IN-OUT. If we take our body as a container, whatever we put into it -food and air- we regard as positive because we need to eat and breathe in order to survive. However, we may find many instances in which there is an axiological clash, i.e. a so-called positive value is in fact negative, or vice versa. For example, "if the container, for example home, is positively charged, being IN it is also positively charged; if the container, for example prison, is negatively charged, being IN it is also negatively charged" (Krzeszowski, 1993, p. 317). It is interesting to know that image schemas underlie all aspects of meaning and cognition and hence they motivate important aspects of how we think, reason, and imagine. Nevertheless, in spite of this importance, they have not yet been sufficiently explored. As argued by Gibbs \& Colston (2006, p. 260), "they are a crucial, undervalued dimension of meaning". As Cortés de los Ríos stated (2010, p. 88) "image schemas are helpful in attaining the goal of persuading and influencing press readers' opinion". Another relevant cognitive tool that "has played a particularly important role in the understanding of embodied language is colour" (Feldman, 2006, p. 66). This is significant for this analysis not only because it conveys meaning but also because it is again the result of our interaction with the world. Colours add meaning because we link them to a certain sensation or feeling. We are not even aware of it, because we have been brought up in a community in which it is established that, for example, white conveys the idea of clean and pure; so even if these inferences are not made consciously they are really powerful. Colours influence the way we react when seeing the covers selected. Cortés de los Ríos (2010) identifies colour as another element that has a strong persuasive value. She explains that it plays a key role in the way we feel about and react to certain magazine covers. Moreover, she highlights that colours have a subliminal effect on us, since we are unconscious of the effect they have and the ideas they induce most of the time. It is well known that in most cultures, black is stereotypically associated with negative things, whereas white is used to refer to pure things.

\subsection{Theory of Multimodal Discourse}

Previous researchers give a theoretical account of pictorial and multimodal cognitive tools (e.g. Forceville, 1996, 2008, 2012; Kress \& Van Leeuwen, 2001; Ventola, Cassily \& Kaltenbacher, 2004). Others have studied the use of these tools in specialized language such as winespeak (e.g. Caballero \& Suárez-Toste, 2008), advertising (e.g. Velasco- 
Sacristán \& Cortés de los Ríos, 2009; Forceville, 1996, 2008, 2009; Koller 2009), and film (e.g. Eggerstsson \& Forceville, 2009; Forceville, 2016).

Forceville \& Urios-Aparisi (2009, p. 5) focus on multimodal discourse and highlight its importance claiming that "a healthy theory of (cognitive) metaphor must systematically study nonverbal and multimodal metaphor". According to Forceville (2009), there are two kinds of metaphors: monomodal and multimodal. While the former refers to those metaphors whose target and source domains belong to one single mode, in the latter they belong to more than one at the same time. The author claims that, although it is difficult to present a thorough compilation of the modes, it is possible to postulate at least nine different modes: "(1) pictorial signs; (2) written signs; (3) spoken signs; (4) gestures; (5) sounds; (6) music; (7) smells; (8) tastes; (9) touch" (Forceville, 2009, p. 23). However, monomodal verbal metaphors have overshadowed the development of multimodality for many years because those have provided the most abundant data (Forceville, 2008, p. 463). But research on multimodal metaphors and metonymies has proven to be really enriching, since "they have a more sensual and emotive impact on viewers and can be understood worldwide more easily since they do not only rely on a particular language" (Forceville, 2008, p. 477). Furthermore, on the one hand, images "[capture] nuances of meaning that would be hard to convey through language and evoke profound emotional responses" (Forceville, 2009, p. 178). On the other hand, words "help the reader identify the precise source or target of a complex metaphor" (Forceville, 2009, p. 181). When both of them are combined, the result is a more powerful cognitive tool that strongly impacts the readership.

Although visual and multimodal metaphors share many of the features of verbal metaphors, they differ from them in several ways, as Forceville stated (2008, pp. 463-464):

First, they have a high degree of specificity. Second, pictorial and multimodal representations have different, medium-determined ways of cueing the similarity between target and source than language has. Third, inasmuch as sounds and pictures are more easily recognized transnationally than (unfamiliar) languages, pictorial and multimodal metaphors. Metaphor in pictures and multimodal representations allow for greater cross-cultural access than verbal ones. Fourth, pictorial and multimodal source domains probably have a stronger emotional appeal than verbal ones.

Yang \& Zhang (2014, p. 2564) also state that "resources such as images, colors, sounds and actions have already been regarded as different type of modes which fulfill the meaning-making".

\section{Corpus and methodology}


The front covers chosen for the analysis are taken from The Economist, a British weekly news magazine. They were published between early 2014 and mid 2016. Over these years, the terrorist attacks and the war in the Middle East forced thousands of people overseas to seek asylum and this issue provided the subject matter for a number of covers. For our purposes, only ten covers were chosen for our study. Our choice is justified on the following grounds:

(a) Covers are particularly good examples of interaction between the modes of language and visuals since both of them are dependent upon each other to convey the message.

(b) The covers included in the corpus of analysis represent both types of terrorist affairs: terrorist attacks and immigration.

The covers were divided into two categories, those belonging to either the WAR or the JOURNEY domains respectively.

\section{THE WAR DOMAIN}

Figure 1: Dating from 5th July 2014

Figure 2: Dating from 10th January 2015

Figure 3: Dating from 21st March 2015

Figure 4: Dating from 6th June 2015

Figure 5: Dating from 21st November 2015

Figure 6: Dating from 14th May 2016

Table 1. The war domain

\section{THE JOURNEY DOMAIN}

Figure 7: Dating from 25th April 2015

Figure 8: Dating from 12th September 2015

Figure 9: Dating from 16th January 2016

Figure 10: Dating from 6th February 2016

Table 2. The journey domain

Our method of analysis focuses on Forceville $(1996,2009,2012)$ and Forceville \& UriosAparisi (2009), who provide clear instructions for the identification of cognitive devices in multimodal discourse. As a result, the following will be addressed: (i) identification of the monomodal or multimodal metaphors and metonymies on the covers, (ii) possible interactions between cognitive tools, (iii) identification of verbal and visual image schemas on which metaphors and metonymies are based and whose purpose is to transmit an evaluative meaning, and (iv) the meaning suggested by colours related to terrorism. Regarding metaphor and metonymy, once we have identified them, we will 
determine whether they are monomodal (verbal or pictorial) or multimodal (pictorioverbal, verbo-pictorial). In addition, we will analyse image schemas because they provide the foundation for the metaphors and metonymies. With respect to this, we will follow the selection made by Evans \& Green (2006, p. 190) for our analysis. Evans \& Green's classification is the following:

(a) space: up-down, front-back, left-right, near-far, centre-periphery, path, straightcurved, scale.

(b) containment: in-out, full-empty.

(c) multiplicity: part-whole, count-mass.

(d) balance: axis balance, point balance equilibrium.

(e) force: compulsion, blockage, counterforce, diversion, enablement, attraction, resistance.

(f) cycle.

(g) attribute: heavy-light, dark-bright, big-small, warm-cold, strong-weak

In addition to this classification, the motion image-schema FORWARD-BACKWARD (Turner, 1991) will be considered. Finally, as for colour, we will use Paul's (2002) chart.

\section{Analysis}

A close analysis of the selected magazine covers has established that there are several domains which, by means of the terrorism verbal and pictorial modes of presentation, cognitively represent the terrorist situation: the WAR domain, (represented by six covers), and the JOURNEY domain (represented by four covers). In addition, the FIRE domain (represented by one cover) is shown to reinforce the WAR domain.

\subsection{The WAR domain}

The WAR domain, frequently used as the source domain that provides a rich knowledge structure for understanding complex phenomena, is represented in our data collection by six covers. 


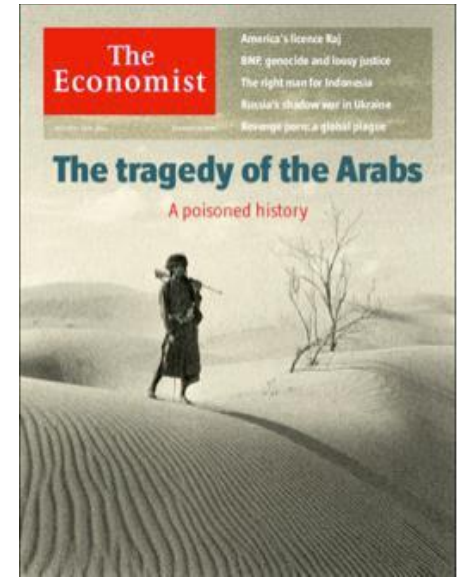

Figure 1. The Economist, 5th July 2014 
The first cover presented in Figure 1 belongs to the WAR domain and was published on the 5th July 2014 issue of The Economist. It conveys the situation of a civilization that

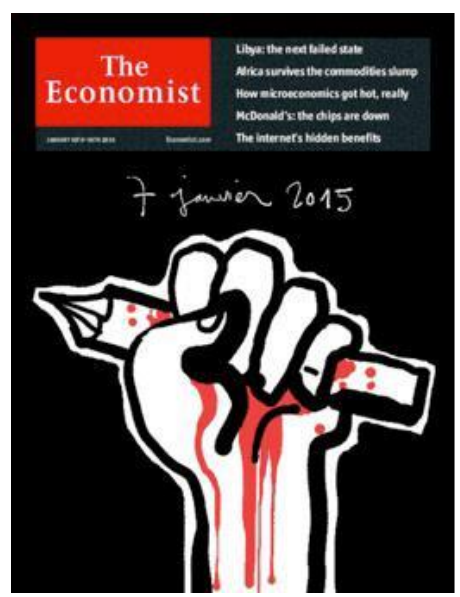

used to lead the world but which is now in ruins. The verbal text "The tragedy of the Arabs. A poisoned history" implies that today the Arab world is in a wretched state. The Middle East is held back by despotism and ravaged by war. In addition, the image of the terrorist implies the intent to dominate this civilization. This verbal-pictorial mode adds to the identification of the TERRORISM IS A CAUSE OF DESTRUCTION FOR THE ARABS metaphor. On the other hand, the image of the terrorist rests on the pictorial metonymy THE OUTFIT FOR THE TERRORISTS (via CLOTHES FOR THE PERSON relationship, resting on the DEFINING PROPERTY OF CATEGORY FOR CATEGORY cognitive principle). Furthermore, this metonymy is based on the following image schemas: movement (FORWARD-BACKWARD) and attribute (STRONG-WEAK), FORWARD and STRONG being valued positively. However, we observe an axiological clash because both of them are negative for the Arabs. The forward movement and the strength of the terrorist portrayed through the carrying of a rifle, evoke the image of terror. Regarding colour, grey is predominant here, chosen because it conveys the impression of solitude, being forgotten, and a colourless life.

Figure 2. The Economist, 10th January 2015

The second cover (Figure 2), dating from 10th January 2015, evokes the Charlie Hebdo attack by gunmen who brought bloodshed to the French capital Paris and its surrounding areas. It began with a massacre at the offices of this satirical magazine on Wednesday 7 January. This cover can be communicated combining verbal and pictorial modes as THE PENCIL IS A WEAPON TO REJECT THE RADICAL ISLAMISM metaphor. It is widely known that the pencil has been considered a symbol of rejection of fanatic Islam. This tool was used in many protests against the fusils to defend freedom of speech. On the other hand, this image rests on the metonymies THE PENCIL USED FOR THE ILLUSTRATOR FROM CHARLIE HEBDO (via THE OBJECT USED FOR THE USER) and THE 
BLOOD FOR THE DEAD (via THE PART FOR THE WHOLE). In addition, these pictorial metonymies are based on attribute schema (BIG-SMALL), BIG being valued positively. However, we observe an axiological clash since the size of the pencil and the hand intensifies the terrorist attack suffered by the French and the damage caused to Europe. Furthermore, we can observe a case of metaphor from metonymy in which the metonymy THE PENCIL USED FOR THE ILLUSTRATOR OF CHARLIE HEBDO is the basis for the metaphorical use.

Very few colours have been chosen for this cover, but they all have a meaning: black stands for mourning after death, and red seems to highlight that, even in the middle of all the grieving, the French will fight back and will not allow the criminals to remain unpunished.

In addition, there is a cultural reference worth mentioning. The raised fist resembles the communist symbol and just as the communists aim to free the working class from the oppression of the powerful, the French are trying to free themselves from the threat and

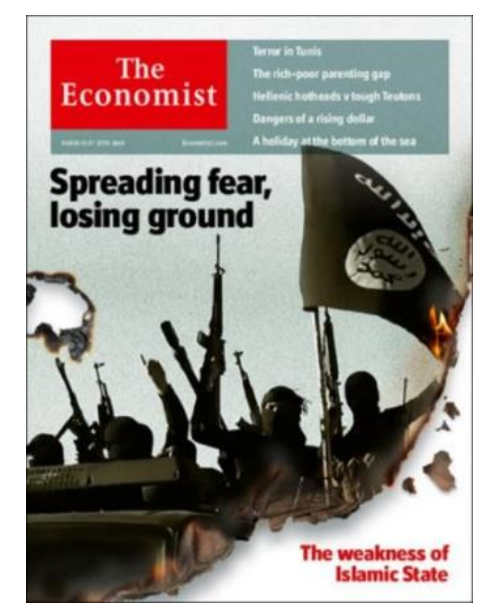

fear of terrorism.

Figure 3. The Economist, 21st March 2015

The third cover (Figure 3), dating from 21st March 2015, evokes the history of pirates and it portrays the pictorial metaphor TERRORISTS ARE PIRATES based on the following image schemas: space (UP-DOWN) and attribute (STRONG-WEAK), UP and STRONG being positive values. However, we observe an axiological clash since the terrorists have their rifles up and their strength is considered a sign of terror. It is known that terrorists are outcasts of society and persecuted by many governments, features traditionally associated with pirates. They have succeeded in making the Western world afraid and unsafe.

This image also belongs to the FIRE domain. Not only do the hands up in the air holding 
weapons remind us of pirates who are about to attack another ship, but also the burnt paper resembles a parchment like a pirate map and its pieces remind us of the Caribbean Islands that pirates used to conquer. The image of a fire threatening the world connotes, through rich mental imagery, the catastrophic crimes that these "pirates" could commit towards our civilization. This cover combines two domains and unequivocally refers to the terror established in the Middle East.

This cover also depicts a verbal metaphor. In light of the target concept (ISLAMIC STATE) to be understood by means of the source domain (LIVING ORGANISM), the cover should be interpreted as that even though Islamic State is still spreading terror, its weaknesses are becoming apparent.

In addition, there is one pictorio-verbal metonymy, TERRORISTS FOR THE ISLAMIC STATE (via THE PART FOR THE WHOLE) and another pictorial, THE ISLAMIC FLAG FOR THE ISLAMIC STATE (which rests on THE PART OF A CATEGORY FOR ENTIRE CATEGORY metonymy).

Regarding colour, black stands for everything that frightens us. When we are young, we are afraid of the dark and the unknown, and that is exactly what these terrorists embody. Furthermore, the colours seem a bit washed-out, like a picture which was taken a long time ago and has now faded.

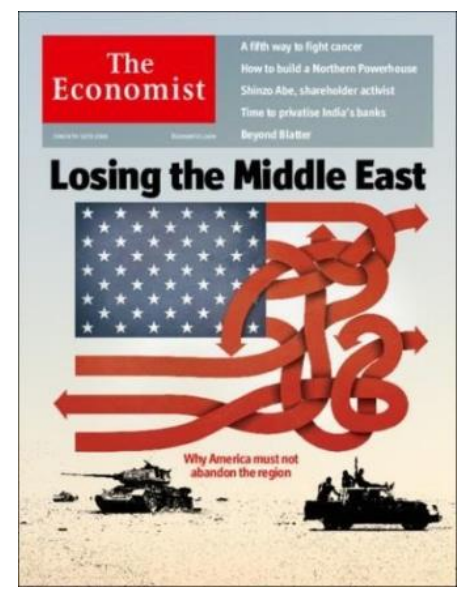

Figure 4. The Economist, 6th June 2015

The fourth cover (Figure 4), dating from 6th June 2015, refers to the difficult situation of America in the Middle East trying to recover the region's stability and its influence there. There is no agreement on whether the US government should be involved in the Middle East affairs or stay out of them. The area has been a war zone for many decades so they are risking reprisals being taken against them. 
This image portrays the pictorial metaphor AMERICA IS A TANGLED ROAD based on the path schema. This image shows how confused the American government is regarding the Middle East, since they have plenty of options but do not know what road to take yet. In addition, we can identify that the container schema is conceptualized. America must stay in the region to save the people from the terrorists. This is negatively valued since the prototypical meaning of IN is positive but in this context it is the opposite, so the region is not secure for American soldiers but they have to follow orders.

It also depicts a pictorial metonymy, THE AMERICAN FLAG FOR THE COUNTRY (which rests on THE PART OF A CATEGORY FOR ENTIRE CATEGORY metonymy) and a verbal one by means of the text "Why America must not abandon the region", A PLACE FOR PEOPLE RESPONSIBLE.

Regarding colours, the pale yellow and blue resemble the view that someone would have of an Arabian desert, their vision hazy from the heat. Likewise, the American government seems to be feeling just as hazy due to all the choices they have, a range as wide as a desert.

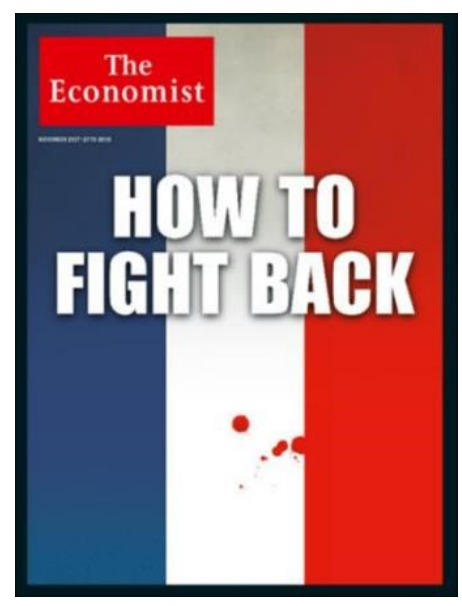

Figure 5. The Economist, 21st November 2015

The fifth cover (Figure 5), dating from 21st November 2015, rests on a number of pictorial metonymies: THE FRENCH FLAG FOR THE COUNTRY (which rests on THE PART OF A CATEGORY FOR ENTIRE CATEGORY metonymy) and THE BLOOD FOR THE DEAD (via THE PART FOR THE WHOLE). The latter is based on the image schema of space (UP-DOWN). The blood stains at the bottom of the flag imply that France has witnessed the death and suffering of its citizens, reinforcing the idea of negativity and being interpreted as a low blow. In addition, France is conceptualized via the force schema. The text "HOW TO FIGHT BACK" in full use of capital letters expresses the idea of how France, as a member of the EU, is looking for a way to deal with other possible terrorist attacks and protect its citizens. It shows how much this tragedy has affected the whole country and how 
everybody is willing to act upon it.

Since the French flag is the cover itself, the colour analysis may seem pointless. However, the fact that the red drops (which represent blood) are placed on top of the white stripe symbolises that the innocence and purity of the people have been damaged forever by the brutality of the attacks.

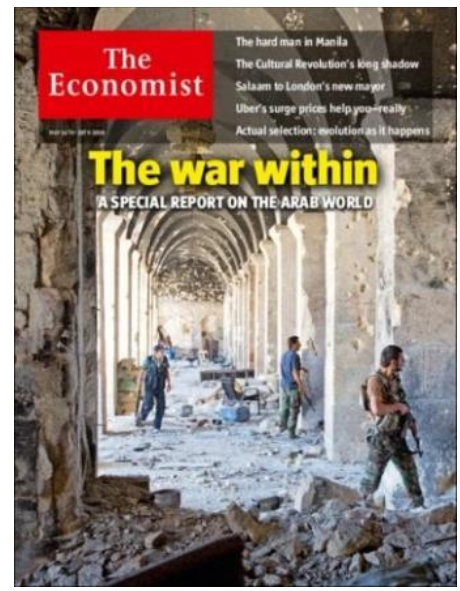

Figure 6. The Economist, 14th May 2016

The sixth cover, dating from 14th May 2016, shows the result of a world oppressed by radicalism, authoritarianism, civil wars, and terrorist groups such as ISIS, a wrecked state whose enemies are not only foreigners, but its own citizens too.

The last cover of this section portrays the pictorio-verbal metaphor THE ARAB WORLD IS A DESTROYED BUILDING. The foundation of this metaphor is the container schema, because it implies that those who remain are doomed to war and destruction; therefore the only chance to improve their prospects is to get out of there, which is why so many migrants are arriving on our shores.

As for pictorial metonymies, we find THE BUILDING FOR THE COUNTRY, and THE OUTFIT FOR THE TERRORISTS (via CLOTHES FOR THE PERSON relationship, resting on the DEFINING PROPERTY OF CATEGORY FOR CATEGORY cognitive principle). Regarding colour, the picture is full of light and white and pale colors are predominant. This may come across as disturbing because we link light with peace and tranquility, adjectives which we would never use to describe a warzone. Therefore, here we find a clash between what we expect and the journalist's choice.

\subsection{The JOURNEY domain}

The JOURNEY domain is frequently used as the source domain in many contexts and is 
represented in our data collection by four covers. In each case they focus on the migration of Syrians in order to find a better life in Europe.

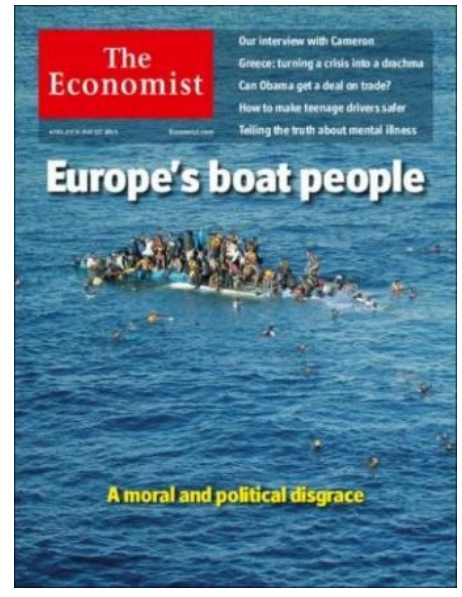

Figure 7. The Economist, 25th April 2015

The seventh cover (Figure 7), dating from 25th April 2015, depicts the situation that the migrants are going through and Europe's approach to this issue. They are fleeing war and hunger so desperately that they are even willing to risk their lives on their journey. Europe has the duty to shelter those who arrive on its shores, but they build fences and send the police to repress them instead. So these migrants find themselves in a terrible situation, the countries that they expected to support them deny them access, but if they went back to Syria they would have to face the problems they were running away from again.

Thus, this cover portrays the pictorio-verbal metaphor MIGRATION IS A BOAT, based on the image schema of container (IN-OUT). IN is a positive value and it means that once they embark on the boat, the migrants do not belong to Syria anymore, but to Europe. However, as a metaphor Europe belongs to the container schema and it is they who decide the fate of these people by only allowing who they want to enter.

This cover also rests on a pictorial metonymy, A FEW MIGRANTS FOR ALL THE MIGRANTS (via A PART FOR THE WHOLE).

There is an overwhelming amount of the colour blue on this cover for the migrants are surrounded by water in the middle of nowhere, probably starving and thirsty with no chance of improving their situation. In other words, the usually inoffensive colour blue becomes threatening and dangerous here. 


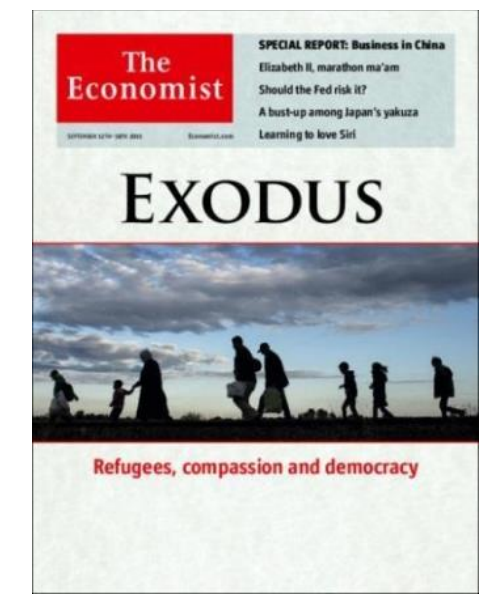

Figure 8. The Economist, 12th September 2015

The eighth cover (Figure 8), dating from 12th September 2015, refers to the escape of migrants from the terror caused by Islamic State. It portrays the pictorio-verbal metaphor SURVIVAL IS AN EXODUS based on the following image schema: movement (FORWARDBACKWARD). The movement schema interacts with the primary metaphor PROGRESS IS FORWARD MOVEMENT. However, we find an axiological clash, because FORWARD is regarded as a positive value, but in this case we should interpret it as negative because these migrants' homeland is not safe for them anymore and their hopes of moving away and being welcomed by Europe are being thwarted. Europe should welcome refugees but migrants are chiefly seen as a burden and although they know that the journey is not easy, they have to advance. Refugees apply for asylum in Europe risking their lives at the hands of people-smugglers. This cover also rests on a pictorial metonymy, A FEW MIGRANTS FOR ALL THE MIGRANTS (via THE PART FOR THE WHOLE).

Regarding colour, the bright blue sky seems to represent their hopes, which cannot be reached. In addition, they are threatened by the grey of the clouds which lead us to foresee a dark future for the migrants, who are themselves depicted as completely black, as if they were already doomed.

It is interesting to highlight a cultural reference evoking the Exodus, traditionally referring to the Jews escaping from Egypt. A comparison between the Jews and the Syrians can be drawn, for both aimed to escape the oppression they were suffering. 


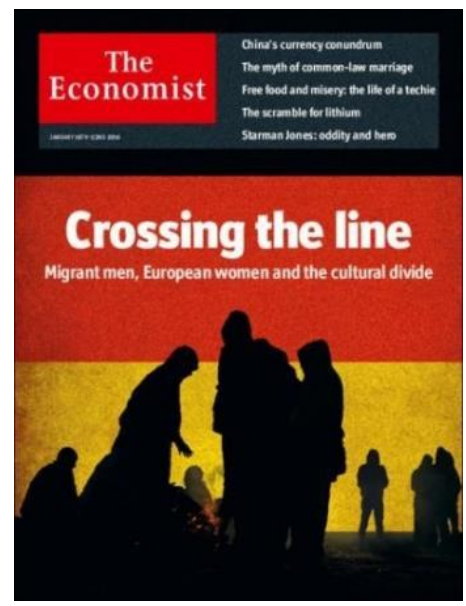

Figure 9. The Economist, 16th January 2016

The ninth cover (Figure 9), dating from 16th January 2016, depicts two situations that are happening in Germany. First of all, Angela Merkel's willingness to welcome asylum seekers into her country has turned into regret after they assaulted some women in Cologne. This is making people choose sides: you either still support the migrants' arrival or you think that they have "crossed the line" and that their values and views on women have nothing to do with the freedom found in the West. Secondly, because now the population is suspicious of them, they are isolated and treated as mere shadows, whose existence is ignored.

This cover portrays the pictorial metaphor MIGRANTS ARE SHADOWS based on the following image schema: space (FRONT-BACK), BACK being negatively valued. The fact that we cannot even see their faces, just the outline of their bodies, is quite meaningful because for us they do not have an identity, we do not sympathize with their stories and their backgrounds.

This cover also rests on a pictorial metonymy, THE GERMAN FLAG FOR THE COUNTRY (which rests on THE PART OF A CATEGORY FOR ENTIRE CATEGORY metonymy).

The most predominant colour is black, which has always been linked to the idea of mourning, pain and suffering, terms than can be applied to the migrants' condition. 


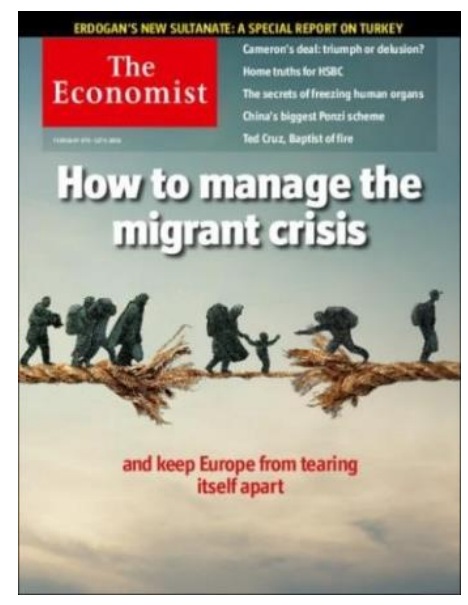

Figure 10. The Economist, 6th February 2016

The tenth cover (Figure 10), dating from 6th February 2016, shows how Europe's welcoming attitude towards migrants and their commitment to support and aid them has faded towards the desire to just get rid of them. Although at the beginning European countries each promised to shelter thousands of migrants, the reality is that only Germany and Sweden have kept their promise.

This cover portrays the following pictorial metaphors: THE ARRIVAL IN EUROPE IS A BROKEN ROPE and MIGRANTS ARE TIGHTROPE WALKERS based on the balance schema. Just like tightrope walkers, migrants know that their journey is risky and success is not guaranteed. In addition, here the rope is breaking, which means that many of them will die before even arriving in Europe. This cover also rests on a pictorio-verbal metonymy, A FEW MIGRANTS FOR ALL THE MIGRANTS (via A PART FOR THE WHOLE).

As for the colours, the people are shown in dark green. Also, the colours in the background are greyish, which is again the idea of transmitting pain and suffering.

\section{Discussion}

The Cognitive Theory of Metaphor and Metonymy and the Theory of Multimodal Discourse allowed us to establish a framework that gave a practical and coherent explanation of the meaning of terrorism through a selection of front covers from The Economist. Verbal and visual modes contribute to the creation of a particular conceptualization of terrorism by means of cognitive tools. The majority of the selected covers combine visual and verbal manifestations of metaphors and metonymies. The frequency of use of metonymies is greater than metaphors. Both cognitive tools are mainly represented visually, less frequently verbally. Terrorism is cognitively represented by means of the WAR and JOURNEY domains. At the same time, the FIRE domain is used 
to reinforce the former. Furthermore, both domains showed on the covers make reference to negative concepts such as destruction, pirates and shadows, reinforcing the domains which frame the analysis. In addition, we have identified a case of metaphor from metonymy (Figure 2). As for image schemas and on the basis of our analysis, it may be said that these are more prevalent in the visual than in the verbal mode. The most recurring ones on which metaphors and metonymies are based are the following: the container schema (IN-OUT), the movement schema (FORWARD-BACKWARD), the attribute schema (STRONG-WEAK, BIG-SMALL), the space schema (UP-DOWN, FRONTBACK), the balance schema, the path schema and the force schema. In addition, the most interesting phenomenon is that there are axiological clashes in half of the covers, meaning that the majority of them carry a negative value. This is due to the topic itself, the cognitive devices are intentionally chosen to depict a terrible reality in which war is forcing people overseas and many countries are being attacked. Following this idea of negative implications, colours such as black and red have been carefully chosen to convey the horrors of war, the blood of the people who have died and the pain and mourning of those who are alive but are left to deal with this loss. Furthermore, cheerful colours such as blue become negative in this context, because it either represents a goal that they cannot achieve (Figures 8 and 10) or a threat (Figure 7). All of them successfully fulfill their intention of evaluating terrorism. Finally, some cultural references were also shown visually and verbally on two covers, the fist used as a communist symbol (Figure 2) and the Jewish exodus from Egypt (Figure 8). These two references are well-known to the average reader and, as a result, the covers have a strong symbolic meaning, seeking the greatest visual impact in order to transmit emotions.

\section{Conclusion}

Our aim in this study was to explore how verbal and pictorial modes contribute to the creation of a particular conceptualization of terrorism by means of cognitive tools on selected covers of The Economist. Our analysis can point out the strong persuasive and rhetorical power of these cognitive tools and their ability to transmit messages and to influence readers. Cognitive tools are more prevalent in the visual than in the verbal mode. This shows how important pictorial representations have become to the communication of terrorism. All these tools help the journalist show reality in a certain way and to shape our thoughts, behaviour, and reactions. In conclusion, we hope to have contributed to filling a gap in the reporting of terrorism through a multimodal analysis of cognitive tools. We are aware that this sample may be limited, there is room for further research and analysis, which will provide us with more information about multimodal metaphors and metonymies, as well as the role of image schemas and colours in the communication of news connected to terrorism. 


\section{About the authors}

$\mathbf{M}^{\mathbf{a}}$ Enriqueta Cortés de los Ríos is a lecturer at the Department of Philology, University of Almería (Spain). Her main research areas are cognitive semantics, axiological linguistics, English for Specific Purposes (ESP) and didactics applied to languages for specific purposes. Her work has been presented at various national and international conferences and has been published in a variety of journals and books. She is a member of the research group 'Languages applied to professional and academic contexts', funded by the Regional Government of Andalucia, Granada University (HUM 641).

Patricia Fernández Alonso entered the University of Almería in 2010 after getting the best mark in the admission test for the Faculty of Humanities. She got a degree in English Studies there, and later she got her Master's degree. She developed then an interest in English for Specific Purposes and in Semantics. Ever since then, she has been teaching English to primary and secondary school students.

\section{LFE Article history}

Paper received: 24th May 2017

Paper received in revised form and accepted for publication: 4th November 2017

\section{References}

Barcelona, A. (2000). Metaphor and Metonymy at the Crossroads. Berlin/New York: Mouton de Gruyter.

Bhatia, A. (2009). The Discourses of Terrorism. Journal of Pragmatics, 41(2), 279-289.

Caballero, R. \& Suárez-Toste, E. (2008). Translating the Senses. Teaching the Metaphors in Winespeak. In F. Boers \& S. Lindstromberg (Eds.), Cognitive Linguistic Approaches to Teaching Vocabulary and Phraseology (pp. 241-259). Berlin/New York: Mouton de Gruyter.

Charteris-Black, J. \& Musolff, A. (2003). Battered 'Hero' or Innocent Victim'? A Comparative Study of Metaphors for Euro trading in British and German Financial Reporting. English for Specific Purposes, 22, 153-176.

Charteris-Black, J. (2006). Britain as a Container: Immigration Metaphors in the 2005 Election Campaign. Discourse and Society, 17(5), 563-581.

Cortés de los Ríos, M. E. (2010). Cognitive Devices to Communicate the Economic Crisis: An Analysis through Covers in The Economist. Ibérica, 20, 81-106. 
Cortés de los Ríos, M. E. \& Azzahara, F. (2014).The Construction of Conceptual Meaning in Print Footwear Ddvertisements. LSP, Professional Communication, Knowledge Management and Cognition, 5(2), 4-23.

Cortés de los Ríos, M. E. \& Corral Hernández, A. (2016). The Promotion of Health and Beauty Tourism through Websites: A Linguistic Analysis. Revista de Lenguas para Fines Especificos, 2(22), 62-83.

Croft, W. \& Cruse, A. (2004). Cognitive Linguistics. Cambridge: Cambridge University Press.

Cruz García, L. (2016). New Perspectives on the Translation of Advertising. Revista de Lenguas para Fines Específicos, 2(22), 9-13.

Cuadrado Esclapez, G. (2005). Análisis semántico-cognitivo de las metáforas utilizadas en la expresión de los fenómenos del universo. Revista Española de Lingüística Aplicada, 1, 85-106.

Díez Velasco, O. (2001). Metaphor, Metonymy, and Image-Schemas: An Analysis of Conceptual Interaction Patterns. Journal of English Studies, 3, 47-63.

Eggerstsson, G. \& Forceville, C. (2009). Multimodal Expressions of the 'Human Victim is Animal' Metaphor in Horror Films. In C. Forceville \& E. Urios-Aparisi (Eds.), Multimodal Metaphor (pp. 429-49). Berlin: Mouton de Gruyter.

Evans, V. \& Green, M. (2006). Cognitive Linguistics: An introduction. Mahwah, NJ: Lawrence Erlbaum Associates.

Feldman, J. (2006). From Molecule to Metaphor: A Neural Theory of Language. Cambridge, MA: The MIT Press.

Forceville, C. (1996). Pictorial Metaphor in Advertising. London: Routledge.

Forceville, C. (2008). Metaphor in Pictures and Multimodal Representations. In R. W. Gibbs (Ed.), The Cambridge Handbook of Metaphor and Thought (pp. 462-482). Cambridge: Cambridge University Press.

Forceville, C. (2009). Non-verbal and Multimodal Metaphor in a Cognitivist Framework: Agendas for Research. In C. Forceville \& E. Urios-Aparisi (Eds.), Multimodal Metaphor (pp.19-42). Berlin: Mouton de Gruyter.

Forceville, C. (2012). Creativity in Pictorial and Multimodal Advertising Metaphors. In R. Jones (Ed.), Discourse and Creativity (pp. 113-132). Harlow: Pearson/Longman.

Forceville, C. (2016). Visual and Multimodal Metaphor in Film: Charting the Field. In K. Fahlenbrach (Ed.), Embodied Metaphors in Film, Television and Video Games: Cognitive Approaches (pp. 1732). London: Routledge.

Forceville, C. \& Urios-Aparisi, E. (Eds.) (2009). Multimodal Metaphor. Berlin: Mouton de Gruyter.

Gibbs, R. \& Coslton, H. (2006). The Cognitive Psychological Reality of Image Schemas and their Transformations. In D. Geeraerts (Ed.), Cognitive Linguistics: Basic Readings (pp. 239-268). Berlin: Mouton de Gruyter.

Goossens, L. (1995). Metaphtonymy: The Interaction of Metaphor and Metonymy in Expressions for Linguistic Action. In L. Goossens, P. Pauwels, B. Rudzka-Ostyn, A. Simon-Vandenbergen \& J. Vanparys (Eds.), By Word of Mouth: Metaphor, Metonymy and Linguistic Action in a Cognitive 
Perspective (Pragmatics and Beyond New Series, 33) (pp. 159-174). Amsterdam: John Benjamins.

Gudrun, H. (2005). Magazine Covers. A Multimodal Pretext-Genre. Folia Linguistica, 39(1), 173-196.

Johnson, M. (1987). The Body in the Mind: The Bodily Basis of Meaning, Imagination and Reason. Chicago: University of Chicago Press.

Judge, A. (2005). Manipulative Metaphors in Response to Terrorism: Semantic and Strategic Confusion from Mixed Metaphors <http://www.laetusinpraesens.org/musings/cuibon08. php> [9/02/2017].

Kheovichai, B. (2015). Metaphorical scenarios in business science discourse. Ibérica, 29, 155-178.

Koller, V. (2009). Brand images: Multimodal metaphor in corporate branding messages. In Forceville, C. \& E. Urios-Aparisi (Eds.), Multimodal Metaphor (pp.45-71). Berlin: Mouton de Gruyter.

Kress, G. \& van Leeuwen, T. (2001). Multimodal Discourse: The Modes and Media of Contemporary Communication. London: Arnold.

Krzeszowski, T.P. (1993). The Axiological Parameter in Preconceptual Image Schemata. In R.A. Geiger \& B. Rudzka-Ostyn (Eds.), Conceptualizations and Mental Processing in Language (pp. 307-330). Berlin: Mouton de Gruyter.

Lakoff, G. (1987). Women, Fire and Dangerous Things. Chicago: The University of Chicago Press.

Lakoff, G. \& Johnson, M. (1980). Metaphors We Live By. Chicago and London: Chicago University Press.

Lakoff, G. \& Turner, M. (1989). More than Cool Reason: A Field Guide to Poetic Metaphor. Chicago: Chicago University Press.

Lakoff, G. \& Johnson, M. (1999). Philosophy in the Flesh: The Embodied Mind and its Challenge to Western Thought. New York: Basic Books.

Langer, T. (2015). Metaphors in Economics: Conceptual Mapping Possibilities in the Lectures of Economics. Procedia Economics and Finance, 25, 308-317.

Negro Alousque, I. (2014). Pictorial and Verbo-Pictorial Metaphor in Spanish Political Cartooning. Círculo de Lingüística Aplicada a la Comunicación, 57, 59-84.

O'Halloran, K. L., et al. (2016). Interpreting Text and Image Relations in Violent Extremist Discourse: A Mixed Methods Approach for Big Data Analytics. Terrorism and Political Violence (pp. 1-21). <http://dx.doi.org/10.1080/09546553.2016.1233871 > [9/02/2017].

Panther, K.; Thornburg, L. \& Barcelona, A. (2009). Metonymy and Metaphor in Grammar. Amsterdam/ Philadelphia: John Benjamins.

Paul, P. (2002). Color By Numbers. American Demographics, 24(2), 30-36.

Pavlíková, K. (2015). (Counter)terrorism Metaphors in the Speeches of Barack Obama (Master's Diploma Thesis). Masaryk University.

Ruiz de Mendoza, F. J. \& Otal Campos, J. L. (2002). Metonymy, Grammar, and Communication. 
Granada: Comares.

Ruiz de Mendoza, F. J. \& Pérez Hernández, L. (2011). The Contemporary Theory of Metaphor: Myths, Developments and Challenges. Metaphor and Symbol, 26, 1-25.

Ruiz de Mendoza, F. J. \& Galera Masegosa, A. (2014). Cognitive Modeling. A Linguistic Perspective. Amsterdam/ Philadelphia: John Benjamins.

Silaski, N. \& Durovic, T. (2010). Catching the Inflation by the Tail: Animal Metaphoric Imagery in the Conceptualisation of Inflation in English. Ibérica, 20, 57-80.

Spencer, A. (2012). The Social Construction of Terrorism: Media, Metaphors and Policy Implications. Journal of International Relations and Development, 15(3), 393-419.

Turner, M. (1991). Reading Minds: The Study of English in the Age of Cognitive Science. Princeton, NJ: Princeton University Press.

Ungerer, F. (2000). Muted Metaphors and the Activation of Metonymies in Advertising. In A. Barcelona (Ed.), Metaphor and Metonymy at the Crossroads (pp. 321-340). Berlin: Mouton de Gruyter.

Ungerer, F. \& Schmid, H. J. (1996). An Introduction to Cognitive Linguistics. Harlow: Longman.

Velasco Sacristán, M ${ }^{a}$ S. \& Cortés de los Ríos, Ma E. (2009). Persuasive Nature of Image Schematic Devices in Advertising: Their Use for Introducing Sexism. Revista Alicantina de Estudios Ingleses, 22, 239-270.

Ventola, E. Cassily, C. \& Kaltenbacher, M. (2004). Perspectives on Multimodality. Amsterdam: John Benjamins.

White, M. (1996). La metáfora en el tratamiento de la crisis monetaria en la prensa británica. Madrid: Servicio de publicaciones de la Universidad Complutense de Madrid.

Wang, M. (2007). Interaction of Image and Language in the Construction of the Theme "Terrorist Threat" in Newspaper Texts: A Critical Study of Media Discourse. US-China Foreign Language, $5(8), 1-12$.

Yang, J. \& Zhang, Y. (2014). Representation Meaning of Multimodal Discourse. A Case Study of English Editorials in The Economist. Theory and Practice in Language Studies, 4(12), 2564-2575. 